historie, som også findes i bogen. Historien om køerne! Vi får lange passager fra Helenas bog om, hvordan det var at passe køer, da hun var en lille pige (s. 34). Køerne gik frit omkring i skoven om sommeren, og det var et kæmpe arbejde for pigerne at samle dem til malkning tre gange dagligt. Det gjordes ved at lytte sig frem til de enkelte køer, som alle kendtes på lyden af deres klokke. Samtidig får vi en detaljeret topografisk beskrivelse, mens vi følger pigerne, der leder efter køer. Vi føres op og ned ad bakkerne, smager på hindbær undervejs og sopper blandt småstenene på søbredden.

Senere berettes om køerne under evakueringerne. Dyrene blev nøje registreret i en særlig bog, så de senere kunne spores af ejermændene. Armstrong fremhæver, hvordan køernes liv forløber parallelt med kvindernes under evakueringen; alle befinder sig fjernt fra deres kendte omgivelser, og alle er hjemløse. Der er problemer med at finde stalde om natten til dyrene og sovested til menneskene. Den forste evakuering ender, og Helena kan vende hjem med to af sine køer. To andre gik undervejs tabt på forskellig vis. Under den anden evakuering har Helena ingen køer at tage vare på og altså heller ingen køer at vende tilbage sammen med. Med denne diskrete konstatering understreger Armstrong det savn, som Helena føler.

Finland, som nok forekommer de fleste af os som den fjerneste og mest eksotiske af Nordens nationer, får via Karen Armstrongs bog en glimrende etnografisk og historisk introduktion. Den karelske diaspora, med familie, nation, narrativ og erindring som omdrejningspunkter, bliver fremstillet og diskuteret med reference til rigtig mange fremtrædende og klassiske antropologer, hvilket gør emnet tilgængeligt og interessant for en bred antropologisk læserskare. Bogen vil med fordel kunne anvendes i undervisning, da den ud over at gå i dybden med sit emne på meget grundig og gennemskuelig facon knytter an til den antropologiske tænkning på flere felter. På en tilfældigt valgt side (s. 72), hvor Armstrong skriver om slægtskab og nation opnår hun at referere til: Lévi-Strauss, Maurice Godelier, Etienne Balibar, David Schneider, Marilyn Strathern, Jane og Peter Schneider og John Borneman. Det drejer sig om rigtige referencer, hvor hun bruger begreber/tanker, som de refererede har lanceret. Der er ikke blot tale om anerkendelsesreferencer. Studerende, lærere og forskere kan have glæde af at læse et antropologisk studie, der således tager sine samtidige - måske lidt ældre - kolleger med på arbejde.

\author{
Kirsten Rønne \\ Mag.scient., antropolog \\ København
}

\title{
Gananath Obeyesekere: Cannibal Talk. The Man-Eating Myth and Human Sacrifice in the South Seas. Berkeley: University of California Press 2005. 320 sider. ISBN 0- 520-24308-0 (pb). Pris: \$21.95.
}

Var det forventningen om at møde menneskeædere, der fik vestlige opdagelsesrejsende til at fortolke ritualiseret menneskeofring blandt indfødte rundt omkring i verden som bevis for kannibalisme? Har kannibalisme i det hele taget eksisteret som kulinarisk praksis andet end under ekstreme forhold, hvor folk har set sig tvunget til at vælge mellem enten at dø af sult eller spise menneskekød? I denne illustrerede samling af otte artikler om kannibalisme og myters magt i det sydlige Stillehav dekonstruerer den srilankanske antropolog Gananath Obeyesekere de europæiske diskurser, som han mener gennem 
tiden har dæmoniseret den kulturelle anden som et primitivt uhyre med monstrøse tilbøjeligheder, herunder kannibalisme. Kapitlerne og empirien er tilpasset den teoretiske ramme, som udstikkes i det første og sidste kapitel. Bogen er forsynet med et forfatter- og emneindeks og tre kort over Aotearoa/New Zealand og Fiji, men mangler desværre en samlet litteraturliste. Alle kilder og henvisninger befinder sig i slutnoterne.

Cannibal Talk er vigtig som kildekritik. Obeyesekere stiller spørgsmålstegn ved den naturlighed, hvormed vestlige skribenter, herunder antropologer, har taget rapporter om kannibalisme i ikke-vestlige samfund for pålydende. Kannibalisme er, hævder han, en myte med rod i europæiske diskurser om „de vilde“. Menneskeædermyternes psykosociale oprindelse finder han i den europæiske kultur selv, især i forestillinger om le corps morcelé (jf. Lacan) og nadverens sakramente, i eventyrverdenens blodige tableau og i straffesystemets brug af tortur, sønderlemmelse, halshugning og udstilling af opskårne menneskekroppe på hjul og stejle.

Udgangspunktet for Cannibal Talk er William Arens' The Man-Eating Myth: Anthropology and Anthropophagy fra 1979, men idéhistorisk peger Obeyesekeres kulturkritik tilbage mod Michel de Montaignes essay om kannibaler, hvori Montaigne bemærker om den brutale kolonialisering af Sydamerika: „Vi kan i sandhed kalde disse folk [de indfødte] barbarer, hvis vi dømmer dem efter fornuftens regler, men ikke i sammenligning med os selv, der overgår dem i enhver form for barbari." Ligesom Arens tvivler Obeyesekere på, at kannibalisme har eksisteret nogen steder i prækoloniale tider. Han mener, at kannibalisme både som myte og som praksis er diskursive konstruktioner, der inden for det europæiske koloniale paradigme podes på andre hegemonisk bærbare diskurser, der ultimativt underbygger kolonialismens metabinære konstruktion: dem og os.

Teoretisk støtter Obeyesekere sig således til Edward Saids kritik af orientalisme og til den brede vifte af såkaldte ,cultural studies“-tiltag, der ofte, men ikke udelukkende, med udgangspunkt i Freuds og Lacans psykoanalyse, litteraturvidenskabelig dekonstruktion, postkoloniale studier, poststrukturalisme, feminisme, narratologi og regionale studier dekonstruerer vestlige diskurser om den kulturelle anden. Obeyesekere vedkender sig med andre ord den type kulturkritik, som de fleste vestlige læsere forbinder med The Subaltern Studies Group, der i årenes løb har tilskyndet forskere som fx Gayatri C. Spivak til at medvirke til at formulere en vigtig dialog med vestlige intellektuelle om kolonialismens byrde, den vedvarende konstruktion af den kulturelle anden og behovet for dekonstruktion af de præmisser, hvorpå det koloniale paradigme hviler. Men i modsætning til de forskere og tænkere, vi normalt finder under paraplybegrebet „cultural studies“, udtrykker Obeyesekere sig på et forbavsende jargonfrit og letlæseligt sprog, der er tilgængeligt for læsere uden teoretisk ekspertise på netop dette område.

Ud over at henvende sig til læsere med interesse for „cultural studies“ og for en kontemporær udlægning af de politiske og især narratologiske overbygninger på det strukturalistiske begreb mythemes, som både Vladimir Propp, Roman Jakobson, Claude LéviStrauss og senest eventyrforskeren Marina Warner har blotlagt, er Cannibal Talk relevant for læsere med særlig interesse i Aotearoa/New Zealand og Fiji og det sydlige Stillehav som region. Undertitlens reference til the South Seas skal således forstås ironisk som et fingerpeg om den brede basis for Obeyesekeres kildemateriale, der ikke begrænser sig til traditionelle etnografiske beskrivelser, men netop går bag om det æggende g-punkt i spændet mellem sydhavsromantikken og menneskeædernes sorte gryde ved at inkludere kildemateriale fra øjenvidnebeskrivelser, logbøger, dagbøger, breve, historiske og etnogra- 
fiske analyser samt litteratur fra mange sider - missionærer og europæiske opdagelsesrejsende, søulke og pirater, hvalfangere og handelsfolk, Herman Melville og Frank Lestringant.

De læsere, der har fulgt debatterne mellem Obeyesekere og Marshall Sahlins siden Obeyesekere i The Apotheosis of Captain Cook: European Mythmaking in the Pacific (1992) udfordrede Sahlins' argument om, at Captain Cook blev modtaget som guden Lono af det hawaiianske folk, kan glæde sig over, at striden mellem de to ,grand old men“ fortsætter. Obeyesekere stikker således til Sahlins, når han efter at have påvist, at John Jacksons beskrivelser af kannibalisme på Fiji er det pure opspind, skriver, at vestlige antropologer typisk fuldkommen ukritisk inkorporerer upålidelige kilder som grundlag for deres analyser og „opfinder komplicerede relationer mellem slægtskab, ægteskab og kannibalisme" og således bidrager til mytedannelse om kannibaler.

Bogens største værdi ligger utvivlsomt i dens diskussion af metode, især i forhold til arkivforskning og historiske kilder, og i dens generelle kulturkritiske diskurs. Analytisk er den imidlertid af en noget broget kvalitet, idet forsøget på at rekonstruere (Obeyesekere følger Lacan og bruger det postmoderne begreb restoration) en indfødt diskurs, som vestlig kolonialisme har formummet bag et slør af kannibalmyter, i virkeligheden understøtter kolonialismens fastlåsning af dem og os. Desuden er det en klar mangel, at Obeyesekere ikke mere specifikt diskuterer menneskeofring som kulturel praksis, da det nok vil overraske mange at høre, at „polynesere ikke praktiserede antropofagi“, kun menneskeofring. Desuden er det ikke altid klart, hvornår Obeyesekere skelner mellem kannibalisme som en psykosocial europæisk fantasiforestilling og antropofagi som selve handlingen at spise menneskekød. En ting er dog sikker: Cannibal Talk giver et originalt perspektiv på et fænomen, der ligesom incest er med til at definere sociale og kulturelle grænser.

Kirsten Møllegaard

M.A., ph.d.-studerende

University of Hawai'i at Manoa

\section{Yasushi Watanabe: The American Family: Across the Class Divide. London \& Ann Arbor: Pluto Press 2005. 229 sider. ISBN 0-7453-1552-6. Pris: £15.99.}

Min nysgerrighed og mine forventninger blev straks vakt, da jeg så denne bogs titel, emne og forfatterens navn. Yasushi Watanabe er japaner og antropolog og har i forbindelse med sin ph.d.-afhandling på Harvard udført feltarbejde i to forskellige sociale miljøer i Boston. Watanabe interviewede informanter fra yankee-eliten i Bostons Beacon Hillområde, de såkaldte „,brahminere“, og fra den irsk-amerikanske arbejderklasse i Sydboston. Bogens struktur er sirligt symmetrisk. Efter introduktionskapitlet kommer de to lange kapitler om „The Yankee Family“ (s. 28-105) og „The Irish Family“ (s. 106-78) og til slut det konkluderende kapitel, der opsummerer og i stor udstrækning gentager de forudgående argumenter og data.

En læser kunne godt, uden i øvrigt at gå ind i problematikken om repræsentativitet, undres over valget af netop disse to sociale grupper til en etnografisk analyse af ,den amerikanske familie“. Watanabe har foretrukket at fastholde det analytiske fokus på ,den amerikanske familie“ og ikke på fx Lloyd Warners „Yankee City“-samfund eller på David Schneiders mere omfattende American Kinship. 